\title{
Diaspora Identities and Psychic Trauma in V.S. Naipaul's A House for Mr.Biswas and The Mimic Men: A Postcolonial Perspective
}

\author{
Mohammed Farman Ullah Bhuiyan
}

Senior Lecturer in English, Uttara University, Bangladesh

bfarmanullah@yahoo.co.uk

\begin{abstract}
V.S. Naipaul is an expatriate from Trinidad whose primary business as a novelist is to project carefully and objectively the complex fate of individuals in a cross-cultural society. This proposal is about the diaspora identities and psychic trauma as represented in V. S. Naipaul's A House for Mr. Biswas and The Mimic Men. This paper attempts to relate how these novels are replete with the theme of identity and individual psychic trauma caused by the aftermaths of colonial rule. A House for Mr. Biswas deals with the theme of isolation, frustration, and negation in a colonized society which turns cruel and callous to the aspiration of the protagonist, Mr. Mohan Biswas. Ralph Singh, on the other hand, is the narrator of The Mimic Men and he is a forty-year-old colonial minister who lives in exile in London. Singh, by writing his memoirs, tries to impose order on his life, reconstruct his identity, and get rid of the crippling sense of dislocation and displacement. This research thus attempts to analyse the different strands of identity to make the work more comprehensive and to radicalize its global demand. Though the question of identity is not new, and much work has been done on this theme of identity but still a few very important strands of identity are still untouched in Naipaul's works. We are going to concentrate on the various types of identity and psychic trauma which are portrayed by V.S. Naipaul through different characters in different situations.
\end{abstract}

Keywords - Diaspora, Displacement, Identity, Psychic, Trauma.

\section{INTRODUCTION}

Jamaican-born British Marxist sociologist Stuart McPhail Hall in one of his articles "Cultural Identity and Diaspora" stated "Diaspora identities are those which are constantly producing and reproducing themselves anew, through transformation and difference." Naipaul's characters also constantly construct and reconstruct themselves to adapt to the new situations. This paper aims at exploring the scope of literary research on V.S. Naipaul focusing on the issue of identity in the most comprehensive sense in his two novels: A House for $\mathbf{M r}$. Biswas (1961) and The Mimic Men (1967). V.S. Naipaul, in his novels, has shown us the struggles and sufferings undergone by his characters to assert their selves through symbols and metaphors. These struggles and sufferings to gain freedom, power, and financial emancipation are very common in the novels of V.S. Naipaul. In the novel $\boldsymbol{A}$ House for Mr. Biswas (1961), the house can be seen as a central symbol for freedom from oppression or humiliation and a representation of desire for selffulfilment and self-actualization. Along with the need to build his own house, he continuously meets obstacles and challenges and even failures in his endeavours. On the other hand, The Mimic Men ( 1967 ) presents and examines a newly independent country in the Caribbean, the island of Isabella, with a pessimistic view: the previous colony has now become independent but the formerly colonized people of the island are unable to establish order and govern their country. They ultimately suffer from dislocation, displacement, fragmentation and loss of identity. I am going to explain and analyse the growth of the protagonists into their lives, the crises they experience out of their dislocation and displacement, and the relentless struggle they undertake against the forces that try to subdue their individual selves.

\section{LITERATURE REVIEW}

V.S. Naipaul is unique in the history of English literature and he became a famous novelist in his lifetime. Writing in The New York Review of Books about Naipaul in 1980, Joan Didion offered the following portrayal of the writer:

The world Naipaul sees is of course no void at all: it is a world dense with physical and social phenomena, brutally alive with complications and contradictions of actual human endeavour. 
....This world of Naipaul's is in fact charged with what can only be described as a romantic view of reality, an almost unbearable tension between the idea and the physical fact ...

Naipaul has been read widely because he had so many gifts as a writer - suppleness, wit and most importantly an unsparing eye for detail- that he could seemingly do whatever he wanted. A lot of works have been done on the writings of Naipaul, and Diaspora identities and psychic traumas remain in the centre of the criticism. Kavita Nandan contributed to this field of research by writing an article entitled "V.S. Naipaul: A Diasporic Vision" in the Journal of Caribbean Literatures. An evaluated full length study is available on "The Quest for Identity in the Works of V.S. Naipaul" by Dr.Veen Gupta. She has discussed only the issue of identity in general. Another book is "V.S. Naipaul: A Writer of Indian Diaspora", edited by Manjeet Inder Singh. It evaluates Naipaul's novels from various points of views. One another full length study is, "The Novels of V. S. Naipaul: Quest for Order and Identity" by Rama Devi. A book entitled "The Novels of V.S. Naipaul: A Study in Theme and Form" by Shashi Kamra also highlights the major themes of Naipaul. A critical work "Critical Perspectives on V.S. Naipaul" by Robert D. Hammer critically examines the works of Naipaul. Another study, "V.S. Naipaul: Critical Essays (Volume I)" by Mohit K Ray presents Naipaul as one of the literature's great travellers, and his absorption into the experience of rootlessness, the alienating effects of colonial past on today's post-colonial people. Bruce King in his book "V.S. Naipaul (Modern Novelists)" critically analysed the situation of the immigrants who leave India and suffer from isolation and dislocation. Keeping all the previous works and findings of the previous writers and researchers in focus, the researcher intends to discover new vistas and avenues to give a broader view of the research on V.S. Naipaul.

\section{METHODS}

I have read and analyzed some canonical or prototypical literary texts, essays, and journal articles on the issue of identity and psychic trauma of the characters portrayed in the writings of V.S. Naipaul. The theoretical perspectives of the literary critics and the opinions of the other writers on Naipaul's writings will be critically evaluated. The representation of the identity crises and the psychological sufferings in the novels $\boldsymbol{A}$ House for Mr. Biswas and The Mimic Men through the characters will be investigated. I will also add the theoretical viewpoint on Naipaul's writing so that I can stand my research with proper strength. I consider the literary theorists such as Frantz Fanon, Gayatri Chakravorty Spivak, Homi Bhabha, Edward Said, Aijaz Ahmad, Aime' Ce'saire ,Ania Loomba, Stuart Hall, Chinua Achebe, Ngũgĩwa Thiong'o and Laura Chrisman of great importance while studying the postcolonial identity problem. I will also analyze some texts as they are appropriate to addressing the research problem. Things Fall Apart, The Shadow Lines, A Bend in the River, An Enigma of Arrival, The Wretched of the Earth, Interpreter of Maladies, The Namesake are the prototypical texts to be discussed and analyzed to get similar or identical issues.

\section{PRELIMINARY RESULTS AND DISCUSSIONS}

The article shows how every individual in his novels suffers from the problems of dislocation and displacement, the state of rootlessness and the loss of identity. It has been found that Naipaul's preoccupation with search for identity, trauma of displacement and the dilemma of 'house' and 'home' has been satisfactorily located in his masterpiece A House for Mr. Biswas. Through the struggles and sufferings of Mr. Mohan Biswas, the novelist re-conceptualizes home and identity from diasporic perspective. Though the novel describes the Hindu community of India, the society it depicts involves a large part of the colonial Caribbean Island. While living in the colonial setting, the immigrant people characterized in the novel like Mr. Biswas constantly struggle to claim their identity which is linked with the question of survival. Their isolation and frustration, love of their own traditional culture and Hindu norms constitute some of the important elements in the novel. Naipaul's incisive diasporic experience is marked by the fragmentation of tradition and history and therefore, the narrative of A House for Mr. Biswas focuses on the protagonist's struggle for self-awareness in which he has inherited the strengths of colonial tradition and history and finds himself in present which is moving towards independence. Identity issue has become ceaselessly salient during the process of cultural alienation, adaptation and assimilation for the exiled intellectuals, among which V. S. Naipaul is a typical and significant one.

Naipaul is an Indian by blood, a Trinidadian by birth and a Briton by citizenship. His literary works, which spans half a century, are generally based on postcolonial contexts and multicultural locations. His growing awareness of the complexities and difficulties of cultural differences, which is exhibited in his literature, leads to his perplexity of identity. Being regarded as a typical and 
significant postcolonial writer, Naipaul takes a strong interest in the exploration of colonial problems and confusions resulted from the withdrawal of imperial order. The novel is a powerful plea for freedom from the tragic burden of colonial exploitation. At the same time, Biswas goes on searching for his roots and for asserting his individual identity. He condemns Hanuman House which symbolizes imperialism in the novel and tries tenaciously to assert his freedom by interrogating all norms of Tulsidom. This assertion of his authentic self motivates him to create something out of nothing.

Both A House for Mr. Biswas and The Mimic Men will be considered as autobiographical bildungsromans because they narrate the lives of young men who create selves as the culmination of their psychological, intellectual, and moral development. The way Naipaul handles his material as a bildungsroman is not a linear procession of events. He does not begin with Ralph's childhood unlike Mr.Biswas; he begins with a glimpse of his student days in London, comes to the present, goes to his childhood, comes to the present, and so on. This is a circular notion of history, and the important thing is the idea, not the technical tools like plot, setting, characterization, etc. In short, when Ralph constructs an independent self and identity, Naipaul simultaneously constructs an independent and authentic writing style. Ralph, as a representative of the Caribbean peoples, feels he does not have a history, a background, a past, a pedigree, a character, and authenticity on which he can base himself. He feels he does not belong to anywhere, including the Caribbean, because of his up rootedness. In short, he suffers from a deep identity crisis and a lack of a sense of belonging. Homi Bhabha - through the paraphrase of the authors of An Introduction to PostColonial Theory - propounds that "English literature is full of 'mimic men' including... Ralph Singh in Naipaul's The Mimic Men. These characters are not to be read in terms of colonial dependency but in terms of mockery, parody, and menace: a disruption of colonial authority" (Childs and Williams 1997: 131).

\section{CONCLUSION}

This article is an attempt to show that Naipaul is worth reading not only for his depiction of interesting characters and plots in his writings but also for the treatment of individual struggle and determination to overcome the psychological, social and financial crises. This article examines how the characters of Naipaul are portrayed amidst postcolonial settings and their struggles to overcome the traumatic experience they faced in their everyday lives. It is also about the way Naipaul deals with the characters in his novels where he sees them as the products of their time and place. As a writer Naipaul had a natural instinct to draw his characters objectively and neutrally. His texts represent the sufferings and pains of the colonized selves on the one hand and their striving and indomitable grit to overcome these sufferings and pains on the other. But bigger than them all was the house, his house.

How terrible it would have been, at this time, to be without it: to have died among the Tulsis, amid the squalor of that large, disintegrated and indifferent family; to have left Shama and the children among them, in one room; worse, to have lived without even attempting to lay claim to one's portion of the earth; to have lived and died as one had been born, unnecessary and unaccomodated.

These are the last sentences from the prologue of the novel A House for Mr. Biswas which summarizes the ultimate need of a man to survive in the hostile world. There are lots of such references in the writings of Naipaul which are enough to prove that Naipaul unlike other writers portrays the postcolonial diaspora identities and their psychic trauma strongly and efficiently. On the other hand, The Mimic Men presents us the story of a post-colonial's self-construction through a critical way of looking upon oneself and the world. The acute change and improvement in Ralph's perception of himself and the world, that is, his keenness in understanding and assessing the problems and difficulties of the "epistemic violence" (Aschcroft, Griffiths, and Tiffin 1993: 91) inflicted on his mind, soul and identity, and his clearsighted perception of the way to gain mental freedom and independence through self-criticism, decolonization of the mind, and writing are a way in the world. Thus the paper is about the unlimited scope of identifying the characters of Naipaul building and rebuilding their selves amidst unending struggles and immeasurable sufferings.

\section{REFERENCES}

[1] ASCHCROFT, B. et al (1990).The Empire Writes Back: Theory and Practice in Post-colonial Literatures.London and New York: Routledge.

[2] CHILDS, P. and WILLIAMS, P. (1997).An Introduction to Post-Colonial Theory.London: Prentice Hall.

[3] DIDION, J. (June 12, 1980 Issue). Without Regret or Hope. The New York Review of Books.

[4] HAMNER, R.D. (1979). Critical Perspectives on V.S. Naipaul. London: Heinmann.

[5] KAMRA, S. (1997). The Novels of V.S. Naipaul: A Study in Theme and Form. New Delhi: Prestige Books. 
[6] KING, B.A. (1993). V.S. Naipaul ( Modern Novelists). London: Macmillan.

[7] MOHAN,C.R. (2004). Postcolonial Situation in the Novels of V.S. Naipaul. Delhi: Atlantic.

[8] NAIPAUL, V.S. (1967). The Mimic Men. New York: Macmillan.

[9] NAIPAUL, V.S. (1961). A House for Mr Biswas. London: Picador, Print.

[10] NANDAN, K\{Kavita\}. ( 2008).V.S. Naipaul: A Diasporic Vision. Journal of Caribbean Literatures.Vol. 5, No. 2. pp. 75-88

[11] RAMADEVI, N. (1996). The Novels of V. S. Naipaul: Quest for Order and Identity. New Delhi: Prestige Books.

[12] RAY, M.K. (2002). V.S. Naipaul: Critical Essays. Delhi: Atlantic.

[13] SINGH, M.I.(1997). V.S. Naipaul: A Writer of Indian Diaspora. Delhi: Rawat Publications. 